\title{
Adrenoleukodystrophy: Magnetic Resonance and diffusion weighted imaging findings
}

\section{Adrenolökodistrofi: Manyetik Rezonans ve Difüzyon Ağırlıklı Görüntüleme Bulguları}

\author{
Mehmet Haydar Atalar
}

Department of Radiology, Cumhuriyet University Faculty of Medicine, Sivas, Turkey,

Corresponding author: Mehmet Haydar Atalar, MD., Department of Radiology, Cumhuriyet University Faculty of Medicine, Sivas, Turkey

E-mail: mhatalar@gmail.com

Received/Accepted: April 23, 2018 / July 10, 2018

Conflict of interest: There is not a conflict of interest.

\section{SUMMARY}

Adrenoleukodystrophy (ALD) is a rare genetic disorder characterized by adrenal failure affecting adrenal cortex and central nervous system and demyelination-related neurological signs. The basic histopathological properties of this disorder are white matter demyelination and axonal loss. In patients diagnosed with a leukodystrophy such as ALD, magnetic resonance imaging (MRI) is the primary imaging modality for characterization, localization, and differential diagnosis of underlying white matter abnormalities. Herein, we aimed to report the contribution of MRI and diffusionweighted imaging (DWI) findings to clinical findings of the disorder in a 9-year-old boy diagnosed with adrenoleukodystrophy.

Keywords: Adrenoleukodystrophy, Brain, Diffusion-weighted imaging, Magnetic resonance imaging.

\section{ÖZET}

Adrenolökodistrofi (ALD), adrenal korteks ve santral sinir sisteminin etkilendiği adrenal yetmezlik ve demiyelinasyona bağlı nörolojik bulgularla seyreden nadir genetik bir hastalıktır. Bu bozukluğun temel histopatolojik özellikleri, beyaz cevherde demiyelinasyon ve aksonal kaybıdır. ALD gibi lökodistrofi tanısı alan hastalarda altta yatan beyaz cevher anormalilerinin karakterizasyonu, lokalizasyonu ve ayırıcı tanısında MRG öncelikli görüntüleme yöntemidir. Bu yazıda adrenolökodistrofi tanısı alan 9 yaşındaki erkek olguda manyetik rezonans görüntüleme ve difüzyon ağırlıklı görüntüleme bulgularının kliniğe katkısını sunmayı amaçladık. 


\section{INTRODUCTION}

Adrenoleukodystrophy (ALD) is a metabolic disorder emerging as a result of the accumulation of very long chain fatty acids in central nervous system and adrenal cortex. Although adrenoleukodystrophy shows an X-linked genetic transmission pattern and thus only affects male children, a milder form of it may occur in an extremely low number of women. This disorder is characterized by adrenal cortex, central nervous system, and testis involvement due to impaired oxidation of long-chain fatty acids. Its incidence varies between 1/25.000 and 1/100.000. Magnetic resonance imaging (MRI) is the principal imaging modality for the characterization, localization, and differential diagnosis of white matter involvement among cases of ALD (1-4). In this paper, we report the contribution of diffusion-weighted imaging (DWI), performed in addition to MRI, to clinical findings in a pediatric patient diagnosed with ALD.

\section{CASE REPORT}

A 9-year-old boy presented with altered behavior, reduced school success, and impaired vision. On neurological examination, his motor and sensory functions were normal; there was no cerebellar sign. The patient was imaged with DWI $(b=800$ $\mathrm{s} / \mathrm{mm}^{2}$ ) studies, including an apparent diffusion coefficient (ADC) map, in addition to multiplane conventional MR sequences. MRI study was performed in a 1.5 Tesla MR unit. Routine serum biochemistry panel was normal. The multiplane conventional MR sequences T1-weighted (T1W) (TR: $560 \mathrm{~ms}$, TE: $9.4 \mathrm{~ms}$ ), T2-weighted (T2W) (TR: $5400 \mathrm{~ms}$, TE:, $89 \mathrm{~ms}$ ), FLAIR (TR: $8002 \mathrm{~ms}$, TE: $96 \mathrm{~ms}$, TI: $1500 \mathrm{~ms}$ ) were obtained. The patient's family history was notable for ALD in her male sibling. In the DWI study, diffusion gradient was set at $\mathrm{b}=0,400$ and $800 \mathrm{~s} / \mathrm{mm}^{2}$ and ADC map images were calculated.

MRI examination revealed bilaterally symmetrical T2A hyperintense lesions that originated from the peritrigonal white matter and involved the posterior leg of the internal capsule and deep white matter at the level of the parietal and occipital lobes (Figs.1A, B). Diffuse white matter involvement with hypointense center and peripheral contrast enhancement was detected after intravenous gadolinium-based contrast agent injection (Fig. 2). DWI revealed increased diffusion in regions with increased T2A signal, and reduced diffusion in regions showing contrast uptake (Figs. 3A, B). Serum cortisol level was 4.3 $\mu \mathrm{g} / 100 \mathrm{dl}$ (normal: $8-28 \mu \mathrm{g} / \mathrm{dl}$ ). Plasma fatty acids were elevated. Phytanic acid and pristanic acid levels were in normal range. On the basis of laboratory and imaging tests, the patient was diagnosed with ALD.

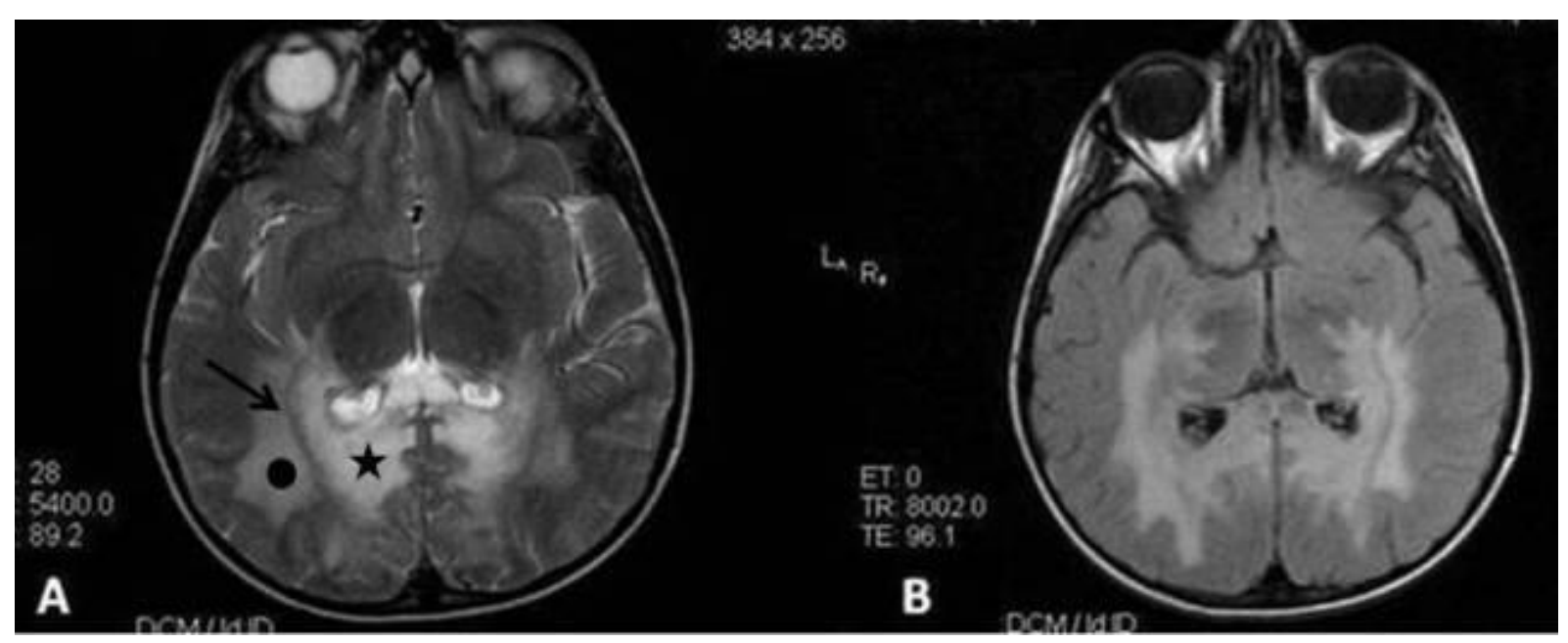

Figure-1: (A) T2W and (B) FLAIR axial MR sections show lesions consistent with symmetrical demyelination that involve peritrigonal deep white matter regions, extending to bilateral fornix major, and affecting splenium. (Star; inner zone, arrow; intermediate zone, circle; peripheral zone). 


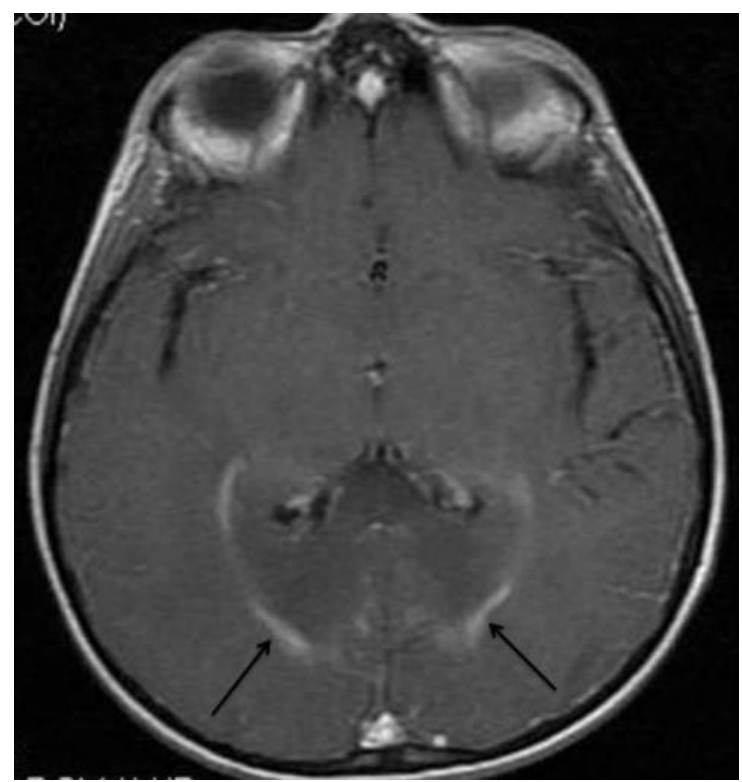

Figure-2: Axial T1W image obtained after the administration of contrast agent shows marked contrast enhancement in the intermediate zone with inflammation (arrow).

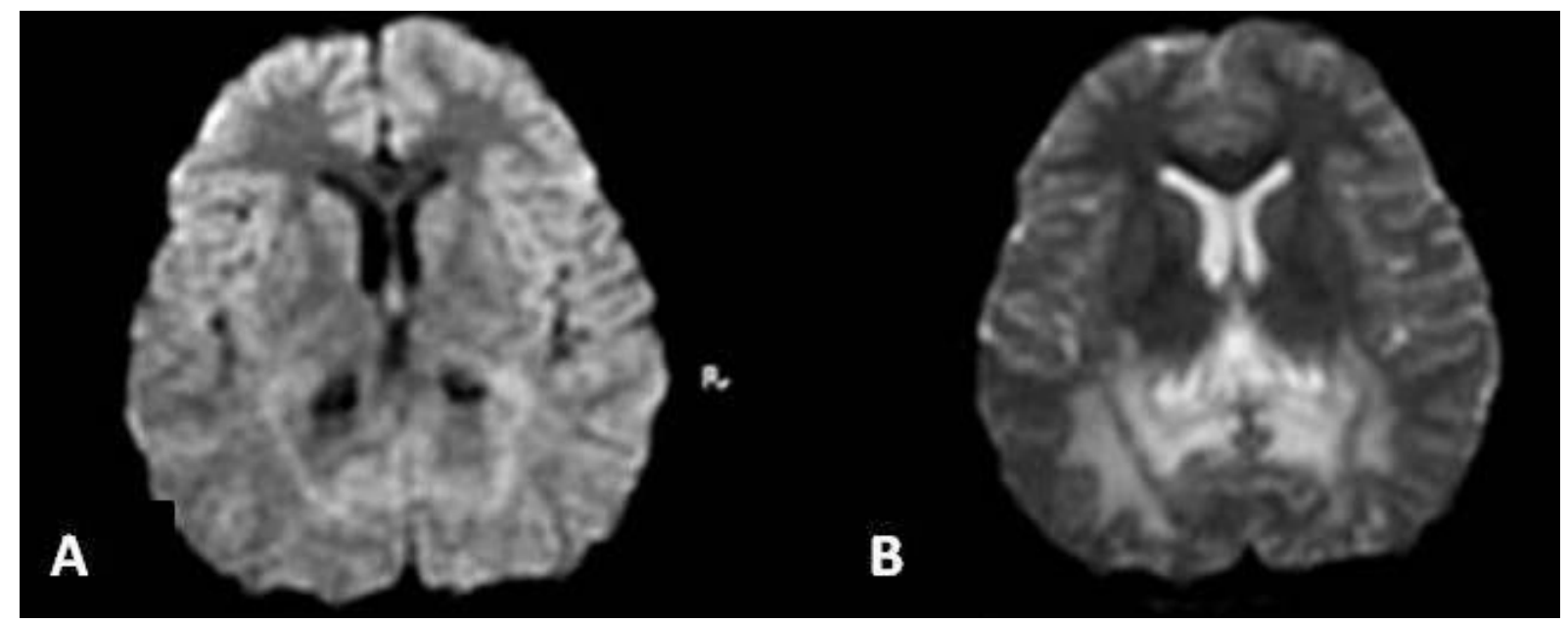

Figure-3: Bilateral parieto-occipital region (A) b: $800 \mathrm{~s} / \mathrm{mm}^{2}$ diffusion-weighted image shows hyperintense linear signal changes consistent with diffusion limitation in contrast enhanced zone and (B) hypointense linear signal changes in ADC image.

\section{DISCUSSION}

Leukodystrophies comprise a broad group of progressive, inherited disorders affecting mainly myelin. ALD is a genetic disorder characterized by adrenal failure involving adrenal cortex and central nervous system, and demyelination-related neurological signs. Having an X-linked genetic transmission, ALD is involves a single peroxisomal dysfunction where the oxidation of very long-chain fatty acids (VLCFA) is defective. Its clinical signs and symptoms appear as a result of VLCFA accumulation. The disorder first appears between the ages of 4 and 8 . Adrenal failure may appear simultaneously with, antecede, or ensue neurological signs and symptoms. The initial symptoms associates with cerebral involvement include learning disabilities, reduced school success, memory disorders, and emotional lability. Introversion, or conversely, aggressive behavior may be seen. Gait disturbance occurs due to lower extremity spasticity. The pathogenesis of the disorder involves demyelination and axonal loss, which are marked in the parietal, occipital, and posterior temporal lobes, and in variable degrees in the frontal lobe. There occurs a marked involvement of the corticospinal and corticobulbar tracts. 
Demyelination typically begins in the parietooccipital region and extends toward corpus callosum. It may extend in anterior and lateral direction as confluent lesions and involve white matter of the temporal, parietal, and frontal lobes but subcortical arcuate fibers are relatively spared. The diagnosis of ALD is primarily based on clinical, MR imaging and biochemical studies ${ }^{1-3}$.

MRI is the principal modality for the characterization, localization, and differential diagnosis of underlying white matter abnormalities among patients with ALD. Demyelination begins from bilateral parietooccipital region and spreads to the splenium of the corpus callosum. Demyelination typically occurs bilaterally and symmetrically. Subcortical U fibers are spared until the late stage of the disorder ${ }^{3-5}$. Atypical ALD cases located in frontotemporal region have been rarely reported ${ }^{6}$.

Histopathologocially, ALD is composed of three zones.

1. Inner zone: irreversible gliosis and scarring occurs in this zone. It appears hypointense in T1W MRI.

2. Intermediate zone: It is where active demyelination and inflammation are found. It appears isointense or slightly hypointense on T2W MRI and enhanced quickly upon IV contrast agent administration.

3. Peripheral zone (edema zone): It is the zone where active destruction and demyelination occurs. It is moderately hyperintense on $\mathrm{T} 2 \mathrm{~W}$ MRI and does not enhance ${ }^{4,5,7}$.

DWI is a functional imaging method based on signal alteration related to random thermal motion of water molecules; it provides important information about brain tissue viability. Compared to conventional MRI, DWI may provide additional information about white matter diseases. Leukodystrophies are characterized by various DWI changes depending on disease stare and histopathological changes. There exist moderate myelin edema in X-linked ALD and metachromatic leukodystrophy ${ }^{4,5,7,8}$. Yüzbaş et al. 5 , in a diffusion-weighted study in a patient with ALD, found a lower ADC value for the inner zone compared to the peripheral zone. In the intermediate zone showing active demyelination, on the other hand, they found a lower ADC level than the two other zones.

In conclusion, it is possible to show active demyelination with MRI and DWI in cases of ALD. Therefore, we are of the opinion that
DWI with contrast-enhanced MRI and ADC maps should be added to routine MRI sequences for the diagnosis and treatment follow-up of ALD.

\section{REFERENCES}

1. Mooser HW. Adrenoleukodystrophy; phenotype, genetics, patogenezis and terapy. Brain. 1997; 120: 1485-1508.

2. Barkovich AJ, Ferriero DM, Bass N, Boyer R. Involvement of the pontomedullary corticospinal tracts; a usefull finding in the diagnosis of $\mathrm{X}$ linked adrenoleukodystropy. AJNR Am J Neuroradiol. 1997; 18: 95-100.

3. Yüzbaş Çekiç P, Biçeroğlu S, Sener RN. Adrenoleukodystrophy: Diffusion MRI findings. Journal of Pediatric Neurology. 2005; 3: 277-8.

4. Sener RN. Atypical X-linked adrenoleukodystrophy: new MRI observations with FLAIR, magnetization transfer contrast, diffusion MRI, and proton spectroscopy. Magn Reson Imaging. 2002; 20: 215-9.

5. Mutlu DY, Firat A, Karakaş HM, Erdem G, Firat Y, Güngör S. Adrenolökodistrofinin Manyetik Rezonans Görüntüleme Bulguları: Spektroskopi Ve Difüzyon Ağırlıklı Görüntülemenin Tanıya Katkısı. İnönü Üniversitesi Tıp Fakültesi Dergisi. 2008; 15: 103 7.

6. Şener RN. Atypical X-linked adrenoleukodystrophy: new MRI observations with FLAIR, magnetization transfer contrast, diffusion MRI, and proton spectroscopy. Magnetic Resonance Imaging. 2002; 20: 215-9.

7. Segawa F, Kishibayashi J, Kamada K, Sunohara N, Kinoshita M. Diffusion anisotropy in cerebral white matter lesion. No To Shinkei. 1994; 46: 765-70.

8. Santosh Rai PV, Suresh BV, Bhat IG, Sekhar M, Chakraborti S. Childhood adrenoleukodystrophy - Classic and variant Review of clinical manifestations and magnetic resonance imaging. J Pediatr Neurosci. 2013; 8: 192-7. 